doi: $10.18575 / \mathrm{msrs} . s m . e .18 .01$

UDC: $616.831-005.1$

COBISS.RS-ID: 7315992

\title{
Relationship between Atrial Fibrillation as a Risk Factor and the Outcome of Ischemic Stroke
}

\section{ABSTRACT}

Introduction: Atrial fibrillation is characterized by uncoordinated atrial activity with consequent deterioration of mechanical function. Patients have 5 times more risk for stroke. These stokes are more severe, more disabling and have a more frequent fatal outcome.

Aim of the Study: The aim was to examine the relationship between atrial fibrillation as risk factor and ischemic stroke.

Patients and Methods: Prospective cohort study was conducted at the Clinic of Neurology, UCC of the Republic of Srpska during the period from January to March 2017. The study included 138 patients who survived ischemic stroke, and atrial fibrillation was identified as a risk factor. Severity of stroke was assessed on admission and discharge with NIHS Scale, and level of disability with Rankin scale. Data was collected and analysed in software programe IBM SPSS Statistics 21.

Results: The sample consisted of 138 patients with ischemic stroke, divided into two groups, with ischemic stroke and atrial fibrillation, and without atrial fibrillation. There were $55.1 \%$ male, and $44.9 \%$ female patients. Atrial fibrillation was more common in female patients (46.8\%) than in male patients $(30.3 \%)$, and there was a significant relationship between gender and atrial fibrillation $\left(\chi^{2}(1, N=138)=3.29\right.$, $p=0.07)$. It was most common in the oldest age group. There was no significant relationship between fatal outcome and atrial fibrillation, gender and age.

Conclusion: Recovery of stoke patients with this comorbidity is much more difficult and slower compared to patients without atrial fibrillation. Early detection and use of oral anticoagulant therapy can significantly decrease stroke risks, and also ease the consequences when stroke already happened.

Key words: stroke, atrial fibrillation, fatal outcome

(Scr Med 2018:49:6-12)

\section{Siniša Miljković ${ }^{1}$ Andrej Blagojević ${ }^{2}$, Tamara Petrušićc ${ }^{3}$}

${ }^{1}$ Clinic of Neurology, UCC of the Republic of Srpska, Banja Luka, Bosnia and Herzegovina ${ }^{2}$ Institute for Physical Medicine and Rehabilitation "Dr Miroslav Zotović", Banja Luka, Bosnia and Herzegovina

${ }^{3}$ Inpharm Co LTD, Banja Luka, Bosnia and Herzegovina

\section{Contact address:}

Siniša Miljković

Clinic of Neurology, University Clinical Centre of the Republic of Srpska

Street address: Dvanaest Beba bb, 78 ooo Banja Luka, Republic of Srpska Bosnia and Herzegovina e-mail: sinisa.miljkovic@kc-bl.com phone number: +387-51-342-548

Submitted: February $9^{\text {th }}, 2018$ Accepted: February 27 $7^{\text {th }}, 2018$ 


\section{Introduction}

Atrial fibrillation is characterized by uncoordinated atrial activity with consequent deterioration of mechanical function. ${ }^{1}$ It is one of the most common cardiac arrhythmias, responsible for one-third of hospitalization due to heart rhythm disorders. The estimated prevalence of atrial fibrillation is $0.4-1 \%$ in the general adult population, and in the United States 2.2 million people have verified atrial fibrillation. ${ }^{2}$ The prevalence increases to about $6 \%$ in patients at the age of 65 years and older and up to $10 \%$ in patients at the age of 80 years and older. ${ }^{3}$ They have a 5 times greater risk of stroke and it is estimated that about $25 \%$ of all strokes in elderly is the consequence of atrial fibrillation. ${ }^{4}$ These strokes are more severe, resulting in more frequent immobility of patients than in strokes of other etiology, and they more often result in the death of the patient. ${ }^{5}$ In accordance with the nature of these events, strokes associated with atrial fibrillation represent a large economic burden of approximately $\$ 8$ billion annually. ${ }^{6}$

The risk of stroke increases from $1.5 \%$ for patients aged 50-59 year to $23 \%$ for those aged $80-89$ years. ${ }^{7}$ Several prospective randomized studies have demonstrated a benefit of oral anticoagulant therapies in the prevention of stroke in patients with atrial fibrillation (AFASAK (Petersen, Boysen et al., 1989), BAATAF, SPAF III (SPAFIII-Trial-Investigators 1996), EAFT Atrial-FibrillationTrial-Investigators 1993). ${ }^{8}$ Risk of stroke can be reduced by about $68 \%$ with anticoagulants that are vitamin $\mathrm{K}$ antagonists. ${ }^{9}$ Oral anticoagulants, either vitamin $\mathrm{K}$ antagonists or non-vitamin $\mathrm{K}$ antagonists (NOAC), effectively reduce thromboembolism associated with atrial fibrillation and, in the long term, oral anticoagulant therapy is recommended for all patients with atrial fibrillation. ${ }^{10}$ Despite the proven benefit and strong desire of patients to prevent stroke, insufficient and improper use of these medications remains a significant problem. Only 20 to $58 \%$ of patients who should receive anticoagulant therapy actually receive one, ${ }^{11}$ and 30-50\% of them stop taking medications within 12 months. ${ }^{12}$

Inadequate use of medication is partly a consequence of the concern of doctors and patients due to the bleeding caused by these medications. Some patients are not able to take anticoagulant medications due to the inability to perform regular laboratory control of INR, while others can't afford NOAC medications. ${ }^{13}$ The occurrence of new anticoagulant medications, such as direct thrombin inhibitor (dabigatran) and direct oral phosphor factor Xa inhibitor (rivaroxaban, apixaban ), which act rapidly, have a stable dose-bound anticoagulant effect, with only a few relevant drug interactions between medications and without the constant need to monitor laboratory values, has significantly contributed to the more frequent administration of oral anticoagulant therapy in patients with atrial fibrillation. ${ }^{14}$ Serbian Association for Atrial Fibrillation Association (SAFA ), in order to gain a better insight into the treatment of atrial fibrillation in the Balkans, has conducted a prospective quarterly study in 7 Balkan countries, Albania, Bosnia and Herzegovina, Bulgaria, Croatia, Montenegro, Romania and Serbia, covering 2712 patients.

The results showed that the quality of oral anticoagulant therapy is still very poor, and that additional efforts are needed to establish a more systematically scientifically proven approach in selecting therapy with the goal of obtaining maximal benefit and minimizing the risks associated with the use of oral anticoagulant therapy and achieving better treatment outcome. ${ }^{15}$

\section{Aim of the Study}

The aim was to examine the relationship between atrial fibrillation as risk factor and ischemic stroke.

\section{Patients and Methods}

A prospective cohort study was conducted at the Clinic of Neurology of the UCC of the Republic of Srpska in the period from January to March 2017. The study included 138 patients who survived an ischemic stroke, and atrial fibrillation was identified as a risk factor. The inclusion criterion was a CT-certified ischemic stroke. The noninclusion criterion was the absence of specific changes on CT and verified intracranial hemorrhage. The severity of stroke for each patient on admission and discharge was assessed by the National Institutes of Health Stroke Scale, and the disability degree by the RANKIN scale. NIHSS scale is a neurological instrument for the objective assessment of stroke severity. It consists of 11 questions related to motor and sensory capabilities of patient, each scored from o to 4 . For each item o, it indicates a normal or orderly function, while a higher score indicates a degree of disability. The minimum score is 0 , while the maximum score is 42. According to the NIHSS scale, the severity of the stroke is determined so that score o indicates the withdrawal of stroke symptoms, the score of 1-4 indicates a mild stroke; the score 5-15 is a moderate stroke, from 16-20 moderate to severe, and from 2140 severe stroke. The degree of disability was assessed with the use of a modified Rankin scale. It consists of 6 degrees of disability, where $o$ is the absence of a deficit, while death is 6th degree.

After the admission to hospital treatment, all patients were examined by the cardiologist, and atrial fibrillation was verified by analyzing the ECG record. Statistical data processing was performed in the software package 
IBM SPSS Statistics 21. From descriptive statistics, frequencies and percentages, minimum and maximum values, arithmetic mean and standard deviation were calculated. Additionally, the distribution of average values of numerical variables in the sample is presented graphically. Relations between categorical variables were tested using a chi square test, with Yates' correction for continuity for matrices $2 \times 2$. The investigation of the significance of differences between RANKIN and NIHSS scores on admission and discharge was done by t-test for paired samples. The differences of the scores in relation to other categorical variables were tested with the t-test for independent samples or ANOVA, depending on the characteristics of the categorical variable. For the margin of statistical significance, a confidence interval 0.05 was taken. Approval of the Ethical Committee of the UCC was obtained, and all patients signed an informed consent before taking part in the study.

\section{Results}

The sample consists of 138 patients classified in two groups. The first group consists of patients with the ischemic stroke without atrial fibrillation and the other with atrial fibrillation. The sample is relatively genderbalanced, with $55.1 \%$ male and $44.9 \%$ female patients. As for the age structure, the sample is categorized into three groups. The first group, 30-49 years, in which there were $7.2 \%$ of patients, the second group, 50-79 years, with the largest proportion of patients at $63.8 \%$ and the group with patients over 80 years of age with $29 \%$ of patients. There were 52 , that is $37.7 \%$ patients out of total number of patients with atrial fibrillation..

Atrial fibrillation is slightly more pronounced in females than in female (46.8\%) than in male patients (30.3\%). Although this difference has not reached statistical significance, it can be said that the reliability value is at its very margin $\left(\chi_{2}(1, \mathrm{~N}=138)=3.29, \mathrm{p}=0.07\right)$. As for the age of patients, this disease is most common in the elderly group of patients (57.5\%), significantly higher in the middle group (32.9\%) and not registered in the youngest group of patients at all. The registered relationship between the age of patients and the incidence of atrial fibrillation is statistically significant ( $\chi^{2}(2, N=$ 138) $=13.57, \mathrm{p}<0.01)$.

In terms of RANKIN score on admission and discharge, the average value on the admission is 3.51 ( $\mathrm{SD}=1.49)$, where the minimum value is 0 , and the maximum 5 . The average RANKIN score on the discharge is 3.00 $(\mathrm{SD}=2.07)$, that is, the minimum value is also $\mathrm{o}$ and the maximum value of 6 . The results of the t-test for the paired samples suggest that, between the admission and discharge, a statistically significant decrease in the score has appeared $(\mathrm{t}, 137, \mathrm{~N}=138)=4.00, \mathrm{p}<0.01)$.

Since the average values themselves do not speak much about the individual values in the sample, the distribution of the results is presented graphically in Picture 1 . We see that 50 respondents had a value 5,31 respondents value 4, and a somewhat lower number of subjects had values from 1 to 3 . Only 3 respondents had a value o. On discharge, the situation is largely changed. Even 21 respondents had value 0 , suggesting that at least 18 respondents had fully recovered. The growth of the number of respondents with values 1 and 2 as well as the fall in the incidence of higher values ( 3,4 and 5 ) is noticeable. At the same time, 22 patients with grade 6 appeared which refers to a fatal outcome during treatment. If we excluded patients who died from the analysis, we would have a significantly lower average score on discharge, which would allow us to conclude that in surviving patients there has been a significant decrease in the average RANKIN score during the treatment.

Picture 1. Distribution of Average Vaules of Rankin Score on Admission and Discharge

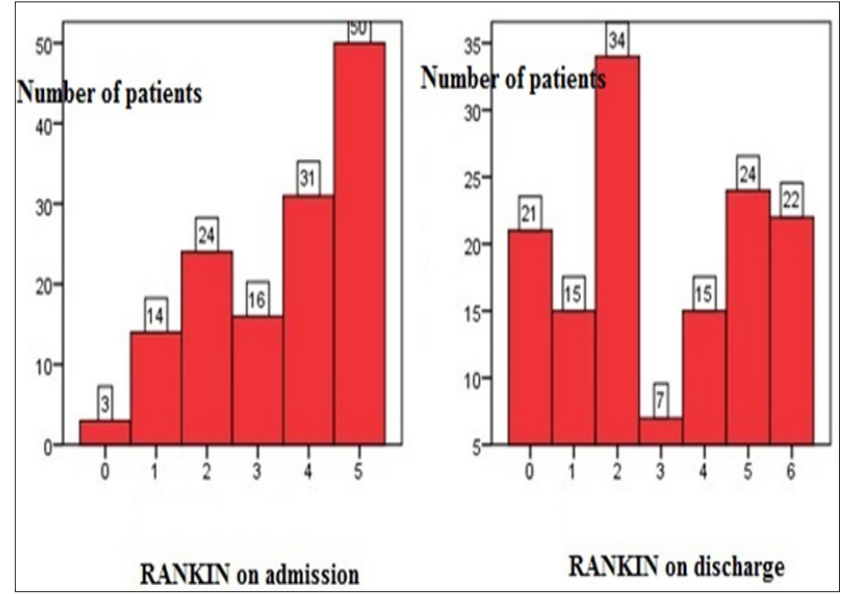

In the case of NIHSS score, the average value on admission was $9.80(\mathrm{SD}=7.51)$, with a minimum value $\mathrm{O}$ and a maximum 40, while on discharge, the average was 11.75 ( $\mathrm{SD}=14.25$ ), with a minimum value $\mathrm{O}$ and maximum 42. The difference in the value on admission and discharge is at the margin of statistical significance ( $\mathrm{t}(137, \mathrm{~N}=138)=-1.95, \mathrm{p}=0.05)$. The fact that the average NIHSS score was higher on discharge may lead to the wrong conclusion that during the treatment, there was no recovery of patients, so for this reason we will present the distribution of results in the sample below, and graphically depict it in Picture 2. On admission, there were 4 registered respondents with NIHSS score $\mathrm{o}$ indicating the absence of stroke symptoms, while the majority of respondents was located in the range of 1 to 15 
(milder and moderate stroke), a slightly smaller number in the range of 16 to 20 (moderate-severe stroke), and the smallest number (total of 11) in the range from 21 to 42 which refers to a severe stroke. On discharge, we see a significant change of scores in the sample. The number of patients without symptoms increased to 15 , suggesting that at least 11 patients were recovered according to the NIHSS scoring criteria. In addition, there was a growing number of patients with low scores indicating weaker symptoms of stroke, and the number of scores on the scale that indicate moderate to severe symptoms was reduced. Here, as in the case of distribution of RANKIN scores on discharge, we see that 22 respondents with a maximum score of 42 appeared, which refers to a death outcome during treatment. It is clear that this growth in the number of respondents with extreme values on the scale significantly influenced the average value, and that by excluding the deceased patients, there would be the reduction of the average NIHSS score during treatment in patients who survived.
Picture 2. Distribution of Average Values of NIHSS Scores on Admission and Discharge and Based on Stroke Severity

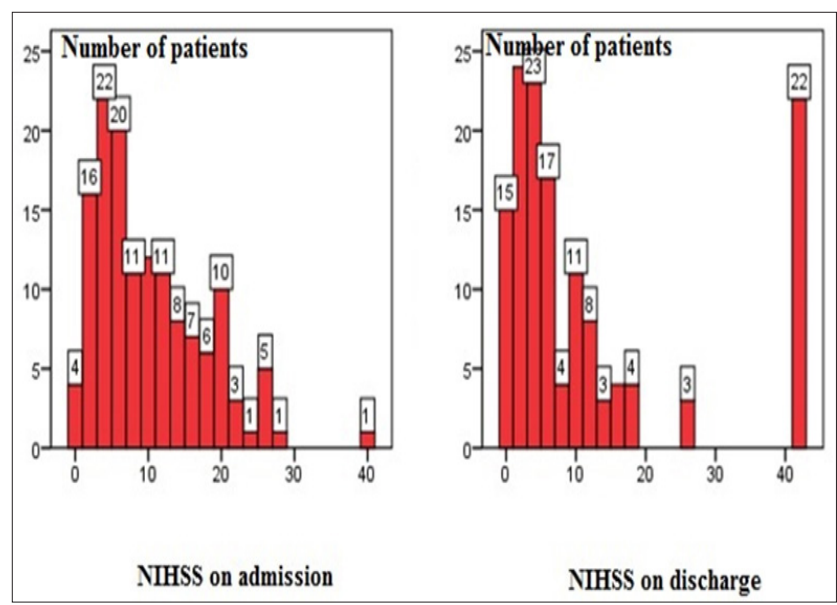

Table 1. Values of NIHSS and Rankin Scores in Patients with Atrial Fibrillation

\begin{tabular}{|c|c|c|c|c|c|c|c|}
\hline Score & $\begin{array}{c}\text { Atrial } \\
\text { fibrillation }\end{array}$ & $N$ & $M$ & $\mathrm{SD}$ & $t$ & df & $p$ \\
\hline \multirow{2}{*}{$\begin{array}{c}\text { RANKIN } \\
\text { on admission }\end{array}$} & Yes & 52 & 3.90 & 1.33 & \multirow[t]{2}{*}{2.48} & \multirow[t]{2}{*}{136} & \multirow[t]{2}{*}{$.014^{*}$} \\
\hline & No & 86 & 3.27 & 1.53 & & & \\
\hline \multirow{2}{*}{$\begin{array}{c}\text { RANKIN } \\
\text { on discharge }\end{array}$} & Yes & 44 & 2.80 & 1.62 & \multirow[t]{2}{*}{1.67} & \multirow[t]{2}{*}{114} & \multirow[t]{2}{*}{.098} \\
\hline & No & 72 & 2.24 & 1.83 & & & \\
\hline \multirow[t]{2}{*}{ NIHSS on admission } & Yes & 52 & 11.19 & 7.25 & \multirow[t]{2}{*}{1.71} & \multirow[t]{2}{*}{136} & \multirow[t]{2}{*}{.090} \\
\hline & No & 86 & 8.95 & 7.58 & & & \\
\hline \multirow[t]{2}{*}{ NIHSS on discharge } & Yes & 44 & 6.89 & 6.00 & \multirow[t]{2}{*}{1.27} & \multirow[t]{2}{*}{114} & \multirow[t]{2}{*}{.208} \\
\hline & No & 72 & 5.49 & 5.64 & & & \\
\hline
\end{tabular}

* significant at $p<0.05$

Since we have previously found that patients who died during the treatment received the maximum RANKIN and NIHSS rates for release, it is clear that the very average value of these scans is directly related to patient mortality. In this regard, when examining the relationship of these values with socio-demographic variables and the presence of atrial fibrillation, the mortality of the patient would have the role of a confounding variable and could lead us to the wrong conclusions. For this reason, when examining the connection with the mentioned variables on discharge, only patients who did not died during treatment were taken into analysis.

From Table 1. we see that in patients with atrial fibrillation, there were consistently higher values of RANKIN and NIHSS scores, both on admission and discharge. This difference, however, reached a statistical significance only in the case of RANKIN score on the admission ( $t$ $(136, N=138)=2.48, p<0.05)$.

In female patients, there were consistently higher values of RANKIN and NIHSS scores, both on admission and discharge. These differences were statistically significant in the case of the RANKIN score on the admission ( $\mathrm{t}(136$, $\mathrm{N}=138)=2.65, \mathrm{p}<0.01)$ and discharge $(\mathrm{t}(114, \mathrm{~N}=138)=$ $3.09, \mathrm{p}<0.01)$, as well as in the NIHSS rate on discharge $(\mathrm{t}(114, \mathrm{~N}=138)=2.49, \mathrm{p}<0.05)$, while the difference in NIHSS was at the margin of statistical significance. 
Table 2. Values of Rankin and NIHSS Scores in Relation to Age of Patients

\begin{tabular}{|c|c|c|c|c|c|c|c|}
\hline Score & Age & $\mathrm{N}$ & $M$ & SD & $\mathrm{F}$ & df & $p$ \\
\hline \multirow[t]{3}{*}{ RANKIN on admission } & 30-49 years & 10 & 2.50 & 1.43 & \multirow[t]{3}{*}{7.74} & \multirow[t]{3}{*}{2} & \multirow[t]{3}{*}{$.001^{\star *}$} \\
\hline & $50-79$ years & 88 & 3.32 & 1.54 & & & \\
\hline & $80-$ over 80 years & 40 & 4.18 & 1.08 & & & \\
\hline \multirow[t]{3}{*}{ RANKIN on discharge } & 30-49 years & 9 & 0.89 & 1.69 & \multirow[t]{3}{*}{7.32} & \multirow[t]{3}{*}{2} & \multirow[t]{3}{*}{$.001^{\star \star}$} \\
\hline & $50-79$ years & 78 & 2.33 & 1.73 & & & \\
\hline & $80-$ over 80 years & 29 & 3.24 & 1.53 & & & \\
\hline \multirow[t]{3}{*}{ NIHSS on admission } & 30-49 years & 10 & 3.70 & 3.27 & \multirow[t]{3}{*}{12.13} & \multirow[t]{3}{*}{2} & \multirow[t]{3}{*}{$.000^{\star \star}$} \\
\hline & 50-79 years & 88 & 8.61 & 6.65 & & & \\
\hline & 80-over 80 years & 40 & 13.93 & 8.18 & & & \\
\hline \multirow[t]{3}{*}{ NIHSS on discharge } & $30-49$ years & 9 & 4.22 & 8.12 & \multirow[t]{3}{*}{5.37} & \multirow[t]{3}{*}{2} & \multirow[t]{3}{*}{$.006^{\star \star}$} \\
\hline & $50-79$ years & 78 & 5.14 & 4.54 & & & \\
\hline & 80 -over 80 years & 29 & 8.93 & 7.11 & & & \\
\hline
\end{tabular}

${ }^{* *}$ significant at $p<0.01$

We see that the RANKIN and NIHSS scores on the admission and discharge were consistently highest in the oldest group of respondents, and that those values decreased over the years, and all registered values were statistically significant at $\mathrm{p}<0.01$, as shown in Table 2 .

During the treatment, 22 patients or $15.9 \%$ of the total sample died. The results of the chi square test suggest that there was not a statistically significant relationship between the mortality of patients and their gender or age. In terms of gender, mortality was slightly more common in male $(19.7 \%)$ than in female respondents (11.3\%). Registered differences in mortality in relation to the age of patients were somewhat more pronounced, so in patients older than 80 years, death was recorded in $27.5 \%$ of patients, while in the younger group, deaths occurred in $10 \%$ and $11.4 \%$ of respondents. The difference in mortality in relation to age was at the very margin of statistical significance $\left(\chi^{2}(2, N=138)\right.$ $=5.63, p=0.06)$, and no mortality associated with the presence of atrial fibrillation in patients was registered.

Since it is known that the mortality of the patient affects the very score of these scales on discharge, in the analysis of the potential correlation of the frequency of fatal outcome with the scales, only the values on admission were used. Also, in order to fulfil the prerequisite for applying the chi square test, the values on these scales were ranked in three categories.

The results of the chi square test suggest that there was a statistically significant relationship between the mortality of patients and NIHSS score on admission $\left(\chi_{2}(2, \mathrm{~N}=\right.$ $138)=11.41, p<0.01)$. The mortality rate was registered in $34.5 \%$ of patients who scored a score above 15 and ranked in the group of patients with moderate-severe or severe stroke, while in patients with moderate stroke (NIHSS 5 - 15) mortality was present in $14.9 \%$, and only $4.8 \%$ patients with mild stroke. As for the RANKIN score, the same tendency of the mortality rate was registered, where mortality was more frequent in higher scores registered on admission, and the tested link was at the margin of statistical significance $(\chi 2(2, N=138)=11.41, p<0.01)$.

\section{Discussion}

Our study has shown the importance of atrial fibrillation as a risk factor for the emergence of ischemic stroke. The results indicate a slightly higher incidence in female population and in the population of patients over the age of 8o. Furthermore, the results show higher scores on NIHSS and Rankin on admission, which indicates that patients with atrial fibrillation have a severe stroke. These results are in correlation with the results of the studies that have been carried out so far and do not deviate from them to a greater extent. Although our study did not show a significant relationship between atrial fibrillation and higher fatal outcome in patients, found in other studies, the results again show that mortality was slightly higher in male population and was correlated with the height of NIHSS and Rankin score on admission. 
The asymptomatic nature of atrial fibrillation, as well as the severity of complications of its inadequate treatment, suggests that greater effort is needed for its early detection and the introduction to therapy. Considering that a large number of patients still remain undiagnosed, and those who have been diagnosed often do not receive adequate therapy, as indicated by our results as well, it is evident that new models of approaches in public health need to be developed to overcome these problems. The emergence of new anticoagulant medications has significantly reduced the resistance to the introduction to this therapy, which was formerly present due to the high risk of bleeding, inability of adequate laboratory monitoring of INR values, and the maintenance of the same in reference values. For now, only one medication from the NOAC group has been registered in our area and its price is still quite high, which is a significant limiting factor for prescribing this therapy, and therefore a better control of atrial fibrillation as a risk factor, especially in older population, which is also visible in our results. In our everyday practice, there are missed opportunities to prevent stroke and our previous failures in improving and implementing prevention strategies should serve as a motive for further work in order to minimize the number of strokes and its consequences.

\section{Conclusion}

From our study, it is evident that higher rates of NIHSS and Rankin score on admission, and particularly on discharge, indicate that patients with atrial fibrillation have a severe stroke, followed by a greater degree of disability. The recovery of stroke patients with this comorbidity is significantly more difficult and slower in relation to patients without atrial fibrillation. New and larger studies are needed to demonstrate a more significant role of atrial fibrillation in the fatal outcome of patients with ischemic stroke. Timely detection and introduction to an adequate therapy can significantly reduce the risk of stroke as well as the consequences of already formed stroke.

\section{References}

1. Fuster V, Ryden LE, Cannom DS, et al. ACC/AHA/ESC 2006 Guidelines for the Management of Patients With Atrial Fibrillation: a report of the American College of Cardiology/American Heart Association Task Force on Practice Guidelines and the European Society of Cardiology Committee for Practice Guidelines (Writing Committee to Revise the 2001 Guidelines for the Management of Patients With Atrial Fibrillation): developed in collaboration with the European Heart Rhythm Association and the Heart Rhythm Society. Circulation. 2006;114(7):e257-354. https://doi.org/10.1161/CIRCULATIONAHA.106.177292 PMID: 16908781.
2. Go AS, Hylek EM, Phillips KA, et al. Prevalence of diagnosed atrial fibrillation in adults: national implications for rhythm management and stroke prevention: the AnTicoagulation and Risk Factors in Atrial Fibrillation (ATRIA) Study. JAMA. 2001;285(18):2370-5. https://doi.org/10.1001/jama.285.18.2370 PMID: 11343485 .

3. Lloyd-Jones D, Adams RJ, Brown TM, et al. Heart disease and stroke statistics-2010 update: a report from the American Heart Association. Circulation. 2010;121(7):e46-e215.

https://doi.org/10.1161/CIRCULATIONAHA.109.192667 PMID: 20019324.

4. Stewart S, Hart CL, Hole DJ, et al. A population-based study of the long-term risks associated with atrial fibrillation: 20-year follow-up of the Renfrew/Paisley study. Am J Med. 2002;113(5):359-64. https://doi.org/10.1016/Sooo2-9343(02)01236-6 PMID: 12401529.

5. Lee WC, Lamas GA, Balu S, et al. Direct treatment cost of atrial fibrillation in the elderly American population: a Medicare perspective. J Med Econ. 2008;11(2):281-98. PMID: 19450086.

6. Caro JJ. An economic model of stroke in atrial fibrillation: the cost of suboptimal oral anticoagulation. Am J Manag Care. 2004;10(14 Suppl):S451-58; discussion S8-61. PMID: 15696909.

7. Lin HJ, Wolf PA, Kelly-Hayes M, et al. Stroke severity in atrial fibrillation. The Framingham Study. Stroke. 1996;27(10):1760-4.

https://doi.org/10.1161/01.STR.27.10.1760 PMID: 8841325 .

8. Atrial-Fibrillation-Investigators. Risk factors for stroke and efficacy of antithrombotic therapy in atrial fibrillation. Analysis of pooled data from five randomized controlled trials. Arch Intern Med 1994;154 (13):1449-57. [PubMed: 8018000 ]

https://doi.org/10.1001/archinte.154.13.1449 https://doi.org/10.1001/archinte.1994.00420130036007 PMid:8018000

9. Petersen P, Boysen G, Godtfredsen J, Andersen ED, Andersen B. Placebocontrolled, randomised trial of warfarin and aspirin for prevention of thromboembolic complications in chronic atrial fibrillation. The Copenhagen AFASAK study. Lancet. 1989;1(8631):175-9.

https://doi.org/10.1016/So140-6736(89)91200-2

10. Camm AJ, Lip GY, De Caterina R, et al. 2012 focused update of the ESC guidelines for the management of atrial fibrillation: an update of the 2010 ESC guidelines for the management of atrial fibrillation. Developed with the special contribution of the European Heart Rhythm Association. Eur Heart J. 2012;33:2719-47. https://doi.org/10.1093/eurheartj/ehs253 PMid:22922413

11. Deplanque D, Leys D, et al. Secondary Prevention of Stroke 
in Patients with Atrial Fibrillation: Factors Influencing the Prescription of Oral Anticoagulation at Discharge. Cerebrovasc Dis 2006;21(56): 372-379.

https://doi.org/10.1159/000091546

PMid: 16490950

12. Gallagher AM, Rietbrock S, Plumb J, van Staa TP. Initiation and persistence of warfarin or aspirin in patients with chronic atrial fibrillation in general practice: do the appropriate patients receive stroke prophylaxis? J Thromb Haemost. 2008;6(9):1500-6.

https://doi.org/10.1111/j.1538-7836.2008.03059.x PMid:18573187

13. Platt AB, Localio AR, Brensinger CM, Cruess DG, Christie JD, Gross R, Parker CS, Price M, Metlay JP, Cohen A, et al. Can we predict daily adherence to warfarin?: Results from the International Normalized Ratio Adherence and Genetics (IN-RANGE) Study. Chest. 2010;137(4):883-9. https://doi.org/10.1378/chest.09-0039

PMid:19903973

PMCid:PMC2851552

14. Nieuwlaat R, Olsson SB, Lip GY, Camm AJ, Breithardt G, Capucci A, Meeder JG, Prins MH, Lévy S, Crijns HJ; Euro Heart Survey Investigators.Guideline-adherent antithrombotic treatment is associated with improved outcomes compared with undertreatment in high-risk patients with atrial fibrillation: the Euro Heart Survey on Atrial Fibrillation. Am Heart J. 2007;153:1006-1012. https://doi.org/10.1016/j.ahj.2007.03.008

15. Potpara TS, Trendafilova E, Dan G-A, et al. The Patterns of Non-vitamin K Antagonist Oral Anticoagulants (NOACs) Use in Patients with Atrial Fibrillation in Seven Balkan Countries: a Report from the BALKAN-AF Survey. Advances in Therapy. 2017;34(8):2043-2057. https://doi:10.1007/s12325-017-0589-5

\section{Povezanost atrijalne fibrilacije kao faktora rizika sa ishodom ishemijskog moždanog udara}

\section{SAŽETAK}

Uvod: Atrijalna fibrilacija se karakteriše nekoordinisanom atrijalnom aktivnošću sa posljedičnom deterioracijom mehaničke funkcije. Pacijenti imaju 5 puta veći rizik za nastanak moždanog udara. Ovi moždani udari su teži, rezultiraju češćom nepokretnošću pacijenata i češćim smrtnim ishodom.

Cilj rada: Ispitati povezanost atrijalne fibrilacije kao faktora rizika sa ishodom moždanog udara.

Ispitanici i metode: Prospektivna kohortna studija je provedena na Klinici za neurologiju UKC Republike Srpske u periodu od januara do marta 2017. god., a obuhvatila je 138 pacijenata sa ishemijskim moždanim udarom. Kao faktor rizika identifikovana je atrijalna fibrilacija koja je verifikovana EKG zapisom. Težina moždanog udara procjenjivana je NIHSS skalom, a stepen onesposobljenosti procjenjivan je RANKIN skalom. Atrijalna fibrilacija verifikovana je analizom EKG zapisa.

Rezultati: Pacijenti su svrstani u dve grupe, sa ishemijskim moždanim udarom i atrijalnom fibrilacijom i bez atrijalne fibrilacije. Od toga je 55,1\% muških i 44,9\% ženskih pacijenata. Češća je kod ženskih (46,8\%) nego kod muških pacijenata (30,3\%). Statistički je značajna veza između pola i atrijalne fibrilacije $\left.\chi^{2}(1, N=138)=3,29, p=0,07\right)$. Veza između starosti i učestalosti atrijalne fibrilacije je statistički značajna $\left(\chi^{2}(2, N=138)=13,57, p<0,01\right)$. Nije utvrđena statistički značajna veza smrtnosti sa prisustvom atrijalne fibrilacije, polom i starošću pacijenta.

Zaključak: NIHSS i Rankin skor na prijemu, a naročito na otpustu ukazuje da pacijenti sa atrijalnom fibrilacijom imaju teži moždani udar, praćen većim stepenom onesposobljenosti. Oporavak je znatno teži i sporiji u odnosu na pacijente bez atrijalne fibrilacije.

Ključne riječi: moždani udar, atrijalna fibrilacija, smrtnost 